\title{
NILAI-NILAI PENDIDIKAN KARAKTER DALAM NASKAH DRAMA OPERA KECOA KARYA N. RIANTIARNO
}

\author{
Agung Prayitno Putro, Herman. J. Waluyo, Nugraheni Eko Wardhani \\ Program Studi Pascasarjana Pendidikan Bahasa dan Sastra Indonesia \\ Universitas Sebelas Maret, Indonesia \\ agungputra9965@gmail.com
}

\begin{abstract}
The purpose of this study is to describe the values of character education for Drama course. It is a qualitative descriptive study. The data were obtained from the play entitled Opera Kecoas written by N.Riantiarno. by looking at the settings, the characters, the plots and some relevant documents. The technique used to collect the data was by document analysis technique. As one form of literary work, Opera Kecoa drama script contains character education values. The values of character education in this drama script are shown through characterizations and events in each chapter. Based on the results of the analysis found ten character education values contained in the drama Opera Kecoa, these values include: social care, tolerance, hard work, discipline, peace,patriotism, friendly, independent, creative, and responsibility. By reason of the values of these characters, the Opera Kecoa drama script can be used as a medium of learning in the college literature.
\end{abstract}

Keywords: character education; learning; literature; drama script; opera kecoa

\begin{abstract}
Abstrak: Penelitian ini bertujuan mendeskripsikan nilai-nilai pendidikan karakter yang terdapat pada sebuah naskah drama. Penelitian ini menggunakan metode deskriptif kualitatif dengan subjek penelitiannya adalah naskah drama Opera Kecoa karya N.Riantiarno. Sumber data diperoleh dari tempat dan peristiwa, informan, naskah drama, dan dokumen. Pengumpulan data menggunakan teknik analisis dokumen. Sebagai salah satu bentuk karya sastra, naskah drama Opera Kecoa memuat nilai-nilai pendidikan karakter. Nilai-nilai pendidikan karakter dalam naskah drama ini ditampilkan melalui penokohan dan alur peristiwa pada setiap babaknya. Berdasarkan hasil analisis maka ditemukan sepuluh nilai pendidikan karakter yang terdapat dalam naskah drama Opera Kecoa, nilainilai tersebut antara lain: peduli sosial, toleransi, kerja keras, disiplin, cinta damai, cinta tanah air, bersahabat, mandiri, kreatif, dan tanggung jawab. Dengan alasan adanya nilai-nilai karakter tersebut maka naskah drama Opera Kecoa dapat digunakan sebagai salah satu media pembelajaran sastra di perguruan tinggi.
\end{abstract}

Kata kunci: pendidikan karakter; pembelajaran; sastra; naskah drama; opera kecoa

Permalink/DOI: http://dx.doi.org/10.15408/dialektika.v7i1.6188 


\section{Pendahuluan}

Pendidikan karakter adalah sistem penanaman nilai-nilai karakter kepada warga sekolah meliputi komponen pengetahuan, kesabaran atau kemampuan, dan tindakan untuk melaksanakan nilai-nilai tersebut. ${ }^{1}$ Pendidikan karakter merupakan pendidikan yang mengembangkan nilai-nilai budaya dan karakter bangsa pada diri siswa, sehingga mereka memiliki dan menerapkan nilai-nilai tersebut dalam kehidupan dirinya sebagai anggota masyarakat dan warga negara yang relegius, produktif, dan kreatif. Senada dengan pendapat tersebut, Sudrajat, menyatakan bahwa karakter merupakan nilai-nilai perilaku manusia yang berhubungan dengan Tuhan Yang Maha Esa, diri sendiri, sesama manusia, lingkungan, dan kebangsaan yang terwujud dalam pikiran, sikap, perasaan, perkataan, dan perbuatan berdasarkan norma-norma agama, hukum, tata karma, budaya dan adat istiadat.

Pendidikan karakter sangat penting, khususnya dalam dunia pendidikan. Hal ini sesuai dengan UU No 20 Tahun 2003 Tentang Sistem Pendidikan Nasional pada Pasal 3, yang menyebutkan bahwa pendidikan nasional berfungsi mengembangkan kemampuan dan membentuk karakter serta peradaban bangsa yang bermartabat dalam rangka mencerdaskan kehidupan bangsa. Pembinaan karakter juga termasuk dalam materi yang harus diajarkan dan dikuasai serta direalisasikan oleh peserta didik atau mahasiswa dalam kehidupan sehari-hari. Kebanyakan pendidikan karakter di tingkat akademis sejauh ini baru menyentuh pada tingkatan pengenalan norma atau nilai-nilai, dan belum pada tingkatan penanaman dan penerapan dalam kehidupan sehari-hari.

Penanaman pendidikan karakter ini akan berdampak terhadap pembentukan perilaku individu. Individu yang berkarakter baik bisa membuat keputusan dan siap mempertanggungjawabkan setiap akibat dari keputusan yang ia buat. ${ }^{4}$ Zamroni Zuhdi, menyatakan bahwa perilaku dapat berwujud menghormati dan menghargai orang lain (respect), keterbukaan dan adil 2012) h. 3

${ }^{1}$ Zainal Aqib dan Sujak, Panduan dan Aplikasi Pendidikan Karakter, (Bandung: Yrama Widya,

${ }^{2}$ Endah Sulistyowati, Implementasi Kurikulum Pendidikan Karakter, (Yogyakarta: Citra Aji Parama, 2012). h.22

${ }^{3}$ Sarwiji Suwandi, Peran Sastra dalam Pendidikan Karakter bagi Peserta Didik. Makalah Seminar Nasional Sastra dalam Rangka Pekan Sastra Himprobsi, FKIP UNS, 2011) h. 2

${ }^{4}$ Suyanto, Model Pembinaan Pendidikan Karakter di Lingkungan Sekolah, (Jakarta: Dirjen Dikdasmen Pendidikan Dasar dan Menengah Kementrian Pendidikan Nasional, 2010), h. 1 
(fairness), dan memiliki kepedulian (caring). ${ }^{5}$ Seseorang yang telah terbentuk karakternya atas tiga nilai tersebut memiliki sikap toleransi yang tinggi; mudah menerima orang lain tanpa memandang latar belakangnya, dan senantiasa mengedepankan keadilan; dan kepedulian terhadap kondisi penderitaan orang lain.

Salah satu media penanaman nilai-nilai pendidikan karakter adalah melalui analisis naskah drama. Hal itu dikarenakan naskah drama tidak hanya sebatas kumpulan dialog semata, tetapi juga meliputi penggambaran watak dan perilaku tokoh dalam suatu peristiwa yang memuat pendidikan karakter.

Salah satu media penanaman pendidikan karakter yang dirasa cocok adalah naskah drama Opera kecoa. Opera Kecoa merupakan satu dari sekian banyak karya N. Riantiarno yang menarik untuk dikaji nilai-nilai pendidikan karakternya dan dijadikan sebagai tolok ukur betapa kerasnya perjuangan hidup kaum urban yang berada di lorong-lorong kota Jakarta.

N.Riantiarno adalah sastrawan Indonesia yang lahir di Cirebon, Jawa Barat, 6 Juni 1949. N.Riantiarno berteater sejak 1965, di Cirebon. Tahun 1967 menamatkan SMA lalu melanjutkan kuliah di Akademi Teater Nasional Indonesia, ATNI, Jakarta. Bergabung dengan Teguh Karya dan ikut mendirikan TEATER POPULER, 1968. Masuk Sekolah Tinggi Filsafat Driyarkara, 1971. Mendirikan TEATER KOMA, 1 Maret 1977. Menulis sebagian besar karya panggungnya, antara lain; Rumah Kertas, J.J Atawa Jian Juhro,Maaf.Maaf.Maaf, Kontes 1980, Trilogi OPERA KECOA (Bom Waktu, Opera Kecoa, Opera Julini), KonglomeratBurisrawa, Pialang Segitiga Emas, Suksesi, Opera Primadona, Sampek Engtay, Banci Gugat, Opera Ular Putih, RSJ atau Rumah Sakit Jiwa, Cinta Yang Serakah, Semar Gugat, Opera Sembelit, Presiden Burung-Burung, Republik Bagong, Tanda Cinta.

Opera kecoa merupakan sebuah naskah drama yang telah berkali-kali dipentaskan dan bisa dianggap puncak karya drama dari seorang N. Riantiarno. Drama ini mengisahkan tentang kehidupan orang-orang dari status sosial menengah ke bawah yang diwakili oleh para pelacur, waria (wadam), dan preman kelas teri yang berjuang untuk mencari penghidupan layak di kota besar. N. Riantiarno melalui Opera kecoa bermaksud menunjukkan kepada pembaca bahwa dalam undercover peradaban kota, terpaku bermacam-macam kisah sosok-sosok yang tengah bergelut dengan sejumput harapan, ketertindasan

${ }^{5}$ Darmiyati Zuhdi, (Ed.), Pendidikan Karakter dalam Perspektif Teori dan Praktik. (Yogyakarta: UNY Press, 2011) h. 166-167 
dalam keakuan, kepasrahan yang dilematis, dan tragedi yang mewarnai sandiwara dengan lakon para manusia marginal.

Kajian naskah drama yang penuh dengan nilai-nilai pendidikan karakter dapat memberikan banyak manfaat bagi pembaca. Sesuai dengan latar belakang dan permasalahan penelitian, maka tujuan umum penelitian ini adalah untuk mendapatkan nilai-nilai pendidikan karakter dan aspek-aspek lain di sekitarnya. Agar lebih mendalami pemahaman pendidikan karakter dalam naskah drama Opera Kecoa, maka perlu dilakukan penelitian yang lebih mendalam.

\section{Metode}

Penelitian ini termasuk penelitian kualitatif dengan menggunakan metode deskriptif. Pendekatan sastra yang digunakan dalam penelitian ini adalah pendekatan mimesis dan penelitian ini juga menggunakan desain metodologi analisis isi (content analysis) untuk menggali isi, pesan,dan nilai-nilai yang terkandung pada objek penelitian.

Sumber data penelitian adalah naskah drama Opera Kecoa karya N.Riantiarno. Konsep ini akan memperjelas langkah selanjutnya, sampai pengambilan data, analisis, dan inferensi. Data yang diinvetarisasi adalah data nilai-nilai pendidikan karakter yang terdapat dalam naskah drama. Inventarisasi data tersebut dilakukan melalui penelusuran unsur tokoh cerita yang berkaitan dengan ujarannya, tindakannya, fungsi peran, serta hubungan antartokoh dan antar fungsi peran, serta paparan narator.

Teknik yang dipakai dalam mengumpulkan data ini adalah teknik dokumentasi. Teknik dokumentasi adalah cara pengumpulan data dengan melihat dan menyelidiki data-data tertulis yang ada di buku, majalah, dokumen, surat, dll. ${ }^{6}$ Teknik ini dioperasionalkan dengan mengumpulkan data yang relevan dengan masalah pokok penelitian. Langkah- langkah pengumpulan data dengan mengidentifikasi dialog-dialog yang mengacu kepada aspek pendidikan karakter dalam teks drama Opera Kecoa dan data tersebut disusun dalam kartu data. Penelitian yang sudah terkumpul kemudian dianalisis dengan langkah-langkah sebagai berikut: mengklasifikasikan aspek pendidikan karakter sesuai dengan pembatasan masalah dalam naskah drama Opera Kecoa karya N. Riantiarno, mendeskripsikan aspek pendidikan karakter yang

\footnotetext{
${ }^{6}$ Imron Rosidi, Ayo senang menulis Karya Tulis Ilmiah, (Jakarta: Media Pustaka. 2005), h. 18
} 
sudah diklasifikasikan dalam dialog-dialog, dan menyimpulkan aspek pendidikan karakter yang dominan dalam naskah drama Opera Kecoa.

\section{Pembahasan}

Opera Kecoa adalah salah satu naskah drama yang tercipta dalam bentuk dialog yang kaya akan nyanyian-nyanyian. Naskah drama ini sarat akan kritik sosial terhadap pemerintahan Orde Baru yang banyak menyudutkan rakyat kecil dengan berbagai penyimpangan birokrasi. Dalam dialog-dialognya pun banyak kata-kata yang vulgar dan anormatif. Meskipun tujuan naskah ini pada awalnya untuk mengkritisi pemerintahan Orde Baru, namun naskah ini dirasa masih relevan dengan kondisi sosial politik pada pemerintahan saat ini.

Melalui imajinasi dan kreativitasnya, Riantiarno dalam drama Opera Kecoa memetaforakan kaum urban miskin, kaum pingggiran, dan kaum di bawah garis kemiskinan secara umum sebagai kecoa. Dalam pandangan umum, pelacur, waria, gelandangan, bandit kelas teri, bromocorah, cabo, germo adalah sampah masyarakat. Namun bagi Riantiarno, sebagai seniman, dia memiliki pandangan yang berbeda dengan pandangan umum tersebut. Jika kebanyakan orang menganggap masyarakat di bawah garis kemiskinan sebagai kaum mayoritas yang selalu inferior, baginya justru kaum di bawah garis kemiskinan adalah komunitas superior karena mereka adalah bagian dari masyarakat yang memiliki kepekaan sosial satu sama lain dalam menyeimbangkan eksistensi dan simbiosis dalam kehidupan. Berdasarkan posisinya sebagai seniman teater, baginya lakon menjadi penting untuk menyuarakan kontrol sosial di masyarakatnya.

\section{Nilai-nilai Karakter}

Sebagaimana yang dikeluarkan Kemendiknas, pendidikan karakter adalah pelaksanaan pendidikan karakter dalam mata pelajaran mengembangkan nilainilai karakter religius, jujur, toleransi, disiplin, kerja keras, kreatif, mandiri, demokratis, rasa ingin tahu, semangat kebangsaan, cinta tanah air, menghargai prestasi, bersahabat/ komunikatif, cinta damai, gemar membaca, peduli lingkungan, peduli sosial, dan tanggung jawab dalam pembelajaran di kelas. ${ }^{7}$

\footnotetext{
${ }^{7}$ Kementerian Pendidikan Nasional, Desain Induk Pendidikan Karakter, (Jakarta Kemendiknas RI, 2010), h.20
} 
Berdasarkan analisis yang dilakukan pada teks drama Opera Kecoa karya N.Riantiarno dapat diperoleh simpulan bahwa, dari 18 pendidikan karakter yang diteliti oleh penulis hanya ditemukan sepuluh nilai pendidikan karakter. Nilai-nilai tersebut adalah peduli sosial, toleransi, kerja keras, disiplin, cinta damai, cinta tanah air, bersahabat, mandiri, kreatif, dan tanggung jawab.

Nilai-nilai karakter dalam naskah Opera Kecoa disampaikan secara tersirat dan tersurat melalui adegan dan dialog-dialognya. Dengan penyampaian yang menggunakan gaya bahasa satire dan sedikit sarkas, amanat dan nilai-nilai yang ingin disampaikan drama tersebut dapat diterima oleh pembaca secara apik.

Nilai toleransi dan peduli sosiallah yang sebenarnya ditekankan dalam naskah drama Opera Kecoa, karena pada dasarnya naskah ini bertujuan untuk menggambarkan realita dan dinamika kehidupan sosial kaum pinggiran yang sering kali dianggap sebelah mata serta dicap kotor oleh sebagian masyarakat. Drama ini menunjukkan betapa kelamnya kehidupan orang-orang pinggiran yang membuat mereka bagaikan kecoa yang hidup di dalam got. Hal ini dibuktikan oleh alur cerita, dialog, dan perilaku antar tokoh yang kebanyakan menyinggung tentang kehidupan sosial dan toleransi terhadap kaum marginal dengan menggunakan gaya bahasa yang satire.

\section{Peduli Sosial}

Peduli sosial menurut kemendiknas adalah sikap dan tindakan yang selalu ingin memberi bantuan pada orang lain dan masyarakat yang membutuhkan. ${ }^{8}$ Dalam naskah drama Opera Kecoa, nilai pendidikan sosial yang nampak adalah saat keterlibatkan para tokoh sebagai kaum pinggiran yang memiliki rasa senasib sepenanggungan dalam menjalani kehidupan di bawah garis kemiskinan. Julini, yang merupakan seorang waria senantiasa menjadi sosok yang ramah kepada para teman seprofesinya, demikian juga Tuminah yang bertindak sangat baik terhadap Roima dan Julini. Hal tersebut terbukti saat Roima dalam keadaan menganggur dan Tuminahlah yang membantunya mendapatkan pekerjaan dari Kumis. Sementara itu, Asnah yang merupakan salah satu tokoh baru, berusaha memberi tempat untuk Roima dan Julini agar membangun rumah di lahan yang menjadi haknya karena ia merasa sudah memiliki sepetak

${ }^{8}$ Kementerian Pendidikan Nasional, Desain Induk Pendidikan Karakter (Jakarta Kemendiknas RI, 2010), h.10 
rumah dan hanya beriniat membantu. Asnah membuktikan bahwa membantu sesama tak harus hanya kepada seseorang yang sudah dikenal saja.

Sebagai sebuah peran penting dalam relasi sosial tentunya nilai pendidikan sosial juga bertindak sebagai penyeimbang interaksi antarmasyarakat dan sebagai penetralisir sekaligus peminimalisir kekacauan sosial yang diakibatkan dari konflik sosial yang bisa saja dengan sengaja atau tidak terjadi di komunitas tertentu. Misalnya saja dalam interaksi awal Tarsih kapada Julini yang terkesan ketus karena menganggap kedatangan Julini dan Roima kembali ke kota hanya untuk meminta bantuannya mengingat kini ia sudah menjadi seseorang yang berkecukupan. Dalam hal ini Tuminahlah yang dapat menunjukkan peran sebagai penetralisir dan peminimalisir konflik sosial di antara Julini dan Tarsih.

Toleransi

Naskah drama Opera Kecoa sangat kental disajikan hubungan antaranggota masyarakat marginal yang memegang teguh rasa solidaritas berdasarkan rasa senasib sepenanggungan. Kehidupan sosial yang banyak mengulas kondisi hidup berhimpitan di kawasan kumuh dan kompleks pelacuran menunjukkan adanya nilai toleransi.

Toleransi ditunjukkan oleh para PSK dan masyarakat pemukiman kumuh lainnya. Mereka saling memberi ruang dan waktu untuk sama-sama mencari nafkah. Tak ada kondisi yang menunjukkan persaingan hingga menimbulkan perselisihan di antara mereka. Meski mereka melakukan pekerjaan yang tidak halal, tetapi berdasarkan nilai pendidikan sosial, kekompakan dan rasa saling menghormati antarpelacur wanita maupun wadam menjadi sebuah objek kajian tersendiri.

Dari uraian nilai sosial di atas juga dapat dilihat nilai toleransi yang begitu kental terasa, karena perbedaan latar belakang dan profesi tidak menjadi penghalang bagi mereka untuk saling peduli. Kisah tersebut juga menunjukan kepada kita agar lebih peka terhadap realita sosial, bahwa kaum pinggiran yang sering dipandang sebelah mata ternyata juga memiliki sikap toleran dan masih memiliki moral selayaknya manusia pada umumnya.

Adapun nilai pendidikan karakter yang terdapat dalam naskah drama Opera Kecoa begitu sarat dengan ajaran namun dikemas dalam bentuk penyimpangan yang melahirkan amanat secara tersirat. Melalui para tokoh yang begitu variatif dengan kekhasan perwatakannya masing-masing, naskah drama ini tampak hidup dan begitu menyajikan pendidikan moral berupa toleransi yang berbobot. 


\section{Cinta Damai}

Cinta damai merupakan sikap dan perilaku yang menyukai harmoni dan bebas dari konflik dan gangguan, suka akan ketenangan (Samani \& Haryanto,2012:127). Sejalan dengan pengertian tersebut, naskah Opera Kecoa memuat nilai cinta damai dalam alurnya. Meski ada banyak hal yang terkesan liar dan penuh dengan upaya hidup yang keras, tetapi dalam proses kehidupan yang berlangsung, sebenarnya pendidikan karakter yang tersirat membawa muatan moral yang menginspirasi, seperti Tibal yang begitu mencintai adiknya yakni Tuminah hingga rela masuk penjara demi membela harga diri dan kehormatan adiknya yang telah direnggut oleh Kumis. Selain itu, Tuminah yang kesuciannya telah direnggut Kumis dan ternyata malah menghianatinya, lebih memilih memaafkan daripada menyimpan dendam yang berlarut-larut.

Roima yang merupakan sosok yang terbiasa berbicara kasar terhadap Julini juga menunjukkan nilai cinta damai, ditunjukkan saat ia mampu meredam kemarahan Tibal kepada Tuminah saat Tibal mengetahui profesi Tuminah selama ia dipenjara. Hal yang sama juga ditunjukkan Roima saat melerai dan menenangkan masa yang mulai memberontak pasca pemukiman kumuh mereka dibakar oleh pejabat.

\section{Cinta Tanah Air}

Cinta tanah air adalah cara berpikir, bersikap, dan berbuat yang menunjukkan kesetiaan, kepedulian, dan penghargaan yang tinggi terhadap bahasa, lingkungan fisik, sosial, budaya, ekonomi, dan politik bangsa (Samani, 2012 :54). Sejalan dengan pengertian tersebut, meskipun naskah Opera Kecoa merupakan bentuk sindiran terhadap kaum-kaum elite dengan menggambarkan dan melibatkan kehidupan kaum pinggiran yang selalu terusir dan dipandang sebelah mata, namun cerita ini juga menunjukkan nilai cinta tanah air yang justru ditunjukkan oleh para cabo.

Nilai cinta tanah air ditunjukkan oleh para cabo yang dengan berbesar hati menerima pajak pendapatan yang dibebankan kepada mereka. Mereka merasa bangga karena hasil keringat mereka bisa disumbangkan demi negara meskipun didapat dari hasil yang haram. Berbeda dengan tokoh oknum pejabat yang dengan entengnya memanfaatkan jabatannya untuk membuat proyekproyek yang justru merugikan negara. 


\section{Persahabatan}

Nilai persahabatan yang luar biasa ditunjukkan oleh Tuminah yang bersedia mengulurkan tangan saat mengetahui Julini dan Roima butuh bantuan. Sebagai teman lama, Tuminah menunjukkan kepeduliannya terhadap Julini dan Roima yang baru saja datang dari kampung. Hal tersebut ditunjukkan saat Tarsih tidak berniat membantu Julini dan Roima, namun Tuminah yang masih menjunjung tinggi persahabatan mereka di masa lalu tetap ingin menerima kedatangan dua sahabatnya tersebut dengan tangan terbuka dan hangat. Jiwa sosial Tuminah tak hanya berhenti sampai di situ saja, terbukti saat Julini dan Roima sudah kembali bertempat tinggal di kawasan kumuh pun Tuminah membantu Roima untuk mendapatkan pekerjaan dari Kumis, hal itu dilakukannya semata-mata karena ingin membantu temannya yang kesulitan mencari pekerjaan.

Di sisi lain, nilai persahabatan masih ditunjukkan oleh Tuminah saat berkomunikasi dengan Tarsih. Sebagai sesama pelacur yang tinggal satu atap di kompleks pelacuran, mereka sama-sama senantiasa saling menguatkan dan saling mendukung.

Sebagai seorang wadam, Julini juga menunjukkan rasa pedulinya kepada teman lamanya yang kini telah dikucilkan oleh keadaan, yaitu Kasijah. Kasijah sebelumnya adalah salah satu pelacur yang dibanggakan dan cukup laris di kompleks pelacuran, tetapi setelah ia tua dan mengidap penyakit kelamin maka ia dikucilkan. Terlebih Kasijah juga telah menjadi gila lantaran terlalu meratapi kondisinya yang kian memburuk. Julini, sebagai seorang teman merasa prihatin dengan kondisi Kasijah.

\section{Disiplin dan Kerja Keras}

Disiplin dan Kerja keras merupakan nilai karakter yang saling berkaitan. Samani \& Haryanto menyatakan bahwa kerja keras merupakan keyakinan akan adanya manfaat moral serta kecakapan melekat yang diperoleh dari bekerja sehingga dapat memperkuat karakter. 'Apabila manusia mempunyai motivasi untuk bekerja keras tentu akan mempertaruhkan apa yang dimilikinya termasuk waktu, oleh karena itu mereka akan lebih disiplin sebagai akibat dari

\footnotetext{
${ }^{9}$ Samani, M.\& Haryanto, Konsep dan Model Pendidikan Karakter, (Bandung: PT Remaja Rosdakarya, 2012), h. 133
} 
pememahaman bahwa hasil kerja keras akan menuai hasil yang hebat apabila disiplin dalam bekerja.

Berkisah tentang kerasnya kehidupan kaum pinggiran tentu saja membuat mereka mau tidak mau harus bersikap mandiri sehingga nilai kerja keras ditemukan dalam naskah drama "Opera Kecoa" ini. Nilai kerja keras terlihat dari berbagai upaya tokoh-tokoh dalam naskah drama Opera Kecoa untuk mencari jalan terbaik dalam mendapatkan uang yang banyak dengan cara yang mudah dan instan. Bagi sebagian yang tinggal di kawasan kumuh dan kompleks pelacuran tentu mereka lebih suka berkecimpung di dunia pelacuran dan perbanditan. Bagi para pelacur dan bandit maka tak perlu waktu lama untuk bisa mendapatkan uang. Hal tersebut jelas merugikan diri mereka sendiri dan orang lain. Ada banyak imbas yang akan timbul dengan pola perkerjaan yang mereka lakukan, hanya saja mereka tidak memikirkannya dalam jangka panjang.

Sementara itu, di kalangan penguasa pun, tampak adanya pola yang hampir sama, hanya saja dengan melibatkan nominal yang lebih banyak kaum borjuis yang dalam hal ini direpresentasikan oleh pejabat menggunakan cara lain lagi, yaitu dengan melakukan tindak korupsi dari proyek pembangunan yang dilakukan untuk kepentingan masyarakat berkat gelontoran dana dari investor asing yang berasal dari Jepang. Meski hal-hal yang dilakukan oleh para tokoh tersebut adalah hal-hal yang negatif tetapi poin penting yang perlu dijadikan bahan pembelajaran adalah kemampuan mereka untuk menginvestasikan uang hasil kerja keras mereka ke dalam tabungan jangka panjang karena adanya kesadaran dalam diri mereka yang tidak akan selamanya berkecimpung dalam profesi mereka tersebut. Contohnya saja Tarsih yang menginvestasikan uang hasil kerja melacurkan diri untuk membeli tanah dan rumah, serta Tuminah dan beberapa cabo lain yang menabungkan uang hasil kerja mereka untuk membuat salon dan warung pascamereka pensiun.

\section{Mandiri}

Kemandirian adalah sikap dan perilaku yang tidak menggantungkan masalahnya pada orang lain dalam penyelesaiannya. Maksud kemandirian dalam konteks ini menurut Jaz dipahami sebagai keadaan atau kondisi seseorang yang dapat berdiri sendiri tanpa bergantung pada orang lain, namun bukan berarti tidak dapat menerima masukan. ${ }^{10}$ Karena ia punya pola atau cara tersendiri dalam berpikir guna menyaring mana yang lebih diprioritaskan.

\section{h. 32}

${ }^{10}$ Jas, Walneg S, Wawasan Kemandirian Calon Sarjana, (Jakarta: Murai Kencana, 2010), 
Nilai kemandirian yang ditunjukkan oleh tokoh-tokoh Opera Kecoa, di antaranya adalah Julini. Bagi julini bagaimana pun keadaannya dan Roima, pantang baginya untuk meratapi keadaan dengan mengemis kepada orang lain. Selama dapat diusahakannya dengan kemampuannya sendiri maka Julini beranggapan bahwa tak sepantasnya ia merengek kepada orang lain sekali pun kepada temannya sendiri seperti Tuminah maupun Tarsih, kecuali jika temantemannya tersebut memberikan pertolongan seikhlas mereka.

Hal lain juga tergambar melalui tokoh salah seorang waria yang melakukan hal ironis untuk menyekolahkan anaknya hingga perguruan tinggi dengan uang hasil berperan ganda antara menjadi tukang becak dan banci. Kegiatan yang dilakukannya dianggapnya telah menjadi sebuah profesi yang mampu menanggung kebutuhan ekonomi dan pendidikan dalam keluarganya menunjukkan sikap yang mandiri.

\section{Kreatif}

Kreativitas juga ditunjukan pada naskah Opera Kecoa ini. Kreativitas merupakan kemampuan olah pikir, olah rasa dan pola tindak yang dapat menghasilkan sesuatu yang inovatif. Meskipun kreativitas tersebut diterapkan pada hal-hal yang bersifat negatif, namun cara tokoh-tokoh dalam naskah tersebut dalam menciptakan inovasi ditengah keterbatasan patut dicontoh apabila diimplikasikan pada hal yang lebih positif.

Sikap kreatif yang ditunjukan Tarsih misalnya, untuk mengembangkan uang hasil kerja kerasnya bertahun-tahun ia investasikan uang itu dengan membeli tanah dan membangun rumah bordil untuk menampung para PSK yang bersedia bekerja dengannya tanpa ia harus melacurkan diri kembali karena ia telah bertindak sebagai germo. Tuminah juga melakukan hal serupa dengan tarsih yang menabungkan uangnya dari hasil melayani para langganan kelas kakap seperti Pejabat dan Tamu untuk melanjutkan kehidupan ketika pensiun dari dunia pelacuran namun tidak dengan menjadi germo.

Berbeda dengan Tarsih dan Tuminah, Julini yang merupakan seorang wadam, juga memiliki cara tersendiri untuk memperoleh penghasilan. Dalam hal ini, Julini lebih suka berinovasi dengan selalu merubah penampilannya sehingga semakin banyak langganan yang menggunakan jasanya. Julini menganggap bahwa dengan penampilan yang sesuai dengan perkembangan tren maka akan mengundang banyak tamu yang otomatis juga dapat menambah penghasilannya, mengingat perannya sebagai pelacur wadam yang pelanggannya tak sebanyak pelacur biasa. Hal yang dilakukan Julini merupakan trik yang 
cerdas karena dengan bergonta-ganti penampilan sesuai permintaan pelanggan menjadikan daya tarik tersendiri dalam proses pemasaran.

\section{Demokrasi}

Orang-orang pinggiran dalam naskah drama Opera Kecoa diposisikan sebagai pejuang. Nilai demokrasi pun begitu terlihat melalui tuntutan keadilan, kemiskinan, pemerintah yang adil, isu perempuan, adat perkawinan, diskriminasi ras dan penyalahgunaan kekuasaan oleh pejabat yang mendomasi keseluruhan alur cerita naskah drama Opera Kecoa.

Opera Kecoa merupakan suara kaum urban kota yang terpinggirkan. Keberpihakan dia kepada kaum pinggiran sendiri juga sudah menjadi pesan. Suara-suara kritik sosial, moral, ekonomi dan politik, terutama dalam menyoal kasus-kasus: (1) penggusuran dengan dengan membumihanguskan perumahan pelacuran dan daerah kumuh; (2) membubarkan masa yang demonstrasi dengan kekuasaan pelor dan bedil; (3) pejabat yang tidak memiliki integritas moral yang baik; dan (4) budaya pejabat korupsi dan kolutif yang semakin marak. Lestyarini menjelaskan bahwa dalam masyarakat multikultural, keterkaitan menjadi unsur penting yang senantiasa diiringi dengan sikap dan watak yang membentuk interaksi yang tidak lain merupakan wujud perilaku demokrasi. ${ }^{11}$

\section{Tanggung Jawab}

Tanggung jawab adalah bentuk sikap dan perilaku seseorang dalam melaksanakan tugas dan kewajiban terhadap diri sendiri, masyarakat, negara, dan Tuhan Yang Maha Esa. Kaitannya dengan naskah drama ini nilai tanggung jawab berimplikasi pada menjaga hubungan antar tokohnya meskipun kehidupan yang digambarkan begitu kasar dan kotor. Tanggung jawab ditunjukkan oleh tokoh Tibal, kakak Tuminah, yang baru saja keluar dari penjara. Tibal begitu menyayangi adik perempuannya satu-satunya hingga mengorbankan diri masuk penjara selama bertahun-tahun karena dakwaan membunuh Kumis. Sebagai seorang kakak lelaki yang bertindak sebagai kakak sekaligus orang tua bagi Tuminah karena keduanya yatim piatu, Tibal menunjukkan sebuah potret nilai pendidikan moral karena membela harga diri dan kehormatan adik perempuannya yang telah dinodai oleh Kumis.

${ }^{11}$ Lestyarini, B, Penumbuhan Semangat Kebangsaan untuk Memperkuat Karakter Indonesia Melalui Pembelajaran Bahasa. Jurnal Pendidikan Karakter. Tahun II Nomor 3, Oktober 2012, 340-354), h.246 
Nilai tanggung jawab juga ditunjukkan oleh tokoh Satpam-1. Sebagai aparat yang bertugas untuk menertibkan keamanan di lingkungan masyarakat, Satpam-1 berusaha untuk menyadarkan para waria yang seringkali mangkal di sekitar kompleks pelacuran dan kawasan kumuh dengan cara yang lebih halus dan persuasif. Meskipun hal tersebut bukan hanya semata-mata karena rasa moralitas internalnya saja tetapi lebih karena disebabkan adanya perintah dari atasannya yaitu Pejabat dan jajarannya yang berusaha untuk menggusur lahan yang selama ini ditempati oleh warga kawasan kumuh dan penghuni kompleks pelacuran dengan cara baik-baik. Nilai tanggung jawab yang ditunjukkan para tokoh sejalan dengan pendapat Lickona yang menyatakan bahwa nilai sikap hormat dan tanggung jawab sangat penting untuk membangun kesehatan pribadi, menjaga hubungan interpersonal, membangun masyarakat yang demokratis dan berprikemanusiaan, dan membantuk dunia yang adil dan damai. $^{12}$

Meskipun naskah ini bercerita tentang kritik sosial dengan lakon dan seting kerasnya kehidupan masyarakat pinggiran, naskah Opera Kecoa dikemas dengan humor-humor cerdas yang sarat akan sindiran. Penggunaan gaya bahasa yang vulgar dan kasar tidak menjadikan pembaca menjadi risih, tetapi ikut tertawa karena pembaca seolah melihat realita yang ada. Karakter julini yang ceplas-ceplos dengan bahasa khas bancinya membuat dialog tidak terkesan serius dan kaku.

\section{Implikasi}

Berdasarkan hasil penelitian di atas, implikasi yang didapat dari hasil penelitian ini adalah memanfaatkan hasil penelitian terhadap pembelajaran apresiasi drama. Penelitian ini merupakan kajian terhadap karya sastra drama, dalam naskah drama Opera Kecoa karya N.Riantiarno kandungan nilai-nilai pendidikan karakter tertuang baik secara tersurat maupun tersirat. Drama yang merupakan karya sastra yang sarat akan pesan akan bermanfaat bagi peningkatan kualitas sumber daya manusia dalam kalangan pendidikan, khususnya untuk menghasilkan sumber daya manusia yang tidak hanya cerdas secara intelektual, namun juga peka secara emosional yang terwujud dalam tingkah laku atau perilaku keseharian mereka.

12 Lickona, Educating for Character, How Our School Can Taech Respect Approach. California: Woodsworth Publishing Company, 2013), h.61 
Naskah drama Opera Kecoa karya N.Riantiarno yang dijadikan sumber data dapat digunakan sebagai media pembelajaran di perguruan tinggi mengingat seting cerita dan penggunaan bahasa yang khas. Bukan hanya untuk pembelajaran apresiasi drama, namun naskah ini juga bisa digunakan untuk contoh materi kuliah pragmatik ataupun sosiolinguistik. Mahasiswa dapat memahami nilai-nilai yang berguna untuk kehiduapan sosial mereka.

\section{Penutup}

Dengan menganalisis pendidikan karakter dalam teks drama Opera Kecoa karya N.Riantiarno, dapat diketahui berbagai macam pendidikan karakter yang terkandung dalam sebuah naskah drama. Bukan hanya sekadar kumpulan dialog-dialog saja, tetapi naskah drama bisa mengajarkan kita tentang pendidikan karakter melalui uraian data-data tersebut. Naskah drama Opera Kecoa karya N.Riantiarno layak digunakan sebagai media dalam pembelajaran drama, karena dari hasil penelitian, teks ini mengajarkan sepuluh pendidikan karakter yang dapat membentuk karakter mahasiswa dalam proses pembelajaran drama. Nilai-nilai tersebut adalah peduli sosial, toleransi, kerja keras, disiplin, cinta damai, bersahabat, mandiri, kreatif, dan tanggung jawab.

\section{Ucapan Terimakasih}

Penulis menyampaikan rasa terima kasih atas petunjuk, dorongan, saran, serta arahan pihak-pihak yang berperan dalam pelaksanaan penelitian sejak rencana penelitian hingga selesainya penulisan artikel ini.

\section{Daftar Pustaka}

Aqib, Zainal, dan Sujak. 2012. Panduan dan Aplikasi Pendidikan Karakter. Bandung: Yrama Widya.

Dewojati, C. 2012. Drama: Sejarah, Teori, dan Penerapannya. Yogyakarta: Penerbit Javakarsamedia.

Hidayatullah, F. 2010. Pendidikan Karakter Membangun Peradaban Bangsa. Surakarta: Yuma Pustaka.

Jas, Walneg S. 2010. Wawasan Kemandirian Calon Sarjana. Jakarta: Murai Kencana.

Kementerian Pendidikan Nasional. 2010. Desain Induk Pendidikan Karakter. Jakarta Kemendiknas RI. 
Lestyarini, B. 2012. Penumbuhan Semangat Kebangsaan untuk Memperkuat Karakter Indonesia Melalui Pembelajaran Bahasa. Jurnal Pendidikan Karakter. Tahun II Nomor 3, Oktober 2012, 340-354.

Lickona. 2013. Educating for Character, How Our School Can Taech Respect Approach. California: Woodsworth Publishing Company.

Miles \& Huberman. 1992. Analisis Data Kualitatif, Buku Sumber tentang Metode-metode Baru. Jakarta: UI Press.

Riantiarno,N. 1986. Opera Kecoa (Cetakan Kedua). Jakarta: Teater Koma.

Rosidi, Imron. 2005. Ayo senang menulis Karya Tulis Ilmiah. Jakarta: Media Pustaka.

Samani, M.\& Haryanto.2012. Konsep dan Model Pendidikan Karakter. Bandung: PT Remaja Rosdakarya.

Santrock, J.W. 1995. Live Span Development. Terjemahan Achmad Chusairi dan Yuda Damanik. Jakarta: Erlangga.

Sayuti, S. A. 2002. Sastra dalam Perspektif Pembelajaran: Beberapa Catatan dalam Sastra Masuk Sekolah. Riris K. Toha-Sarumpaet (Ed.). Magelang: Indonesia Tera.

Sudrajat. 2010. Membangun Budaya Sekolah Berbasis Karakter Terpuji. Pendidikan Karakter dalam Perspektif Teori dan Praktik. Yogyakarta: UNY Press.

Sulistyowati, Endah. 2012. Implementasi Kurikulum Pendidikan Karakter. Yogyakarta: Citra Aji Parama.

Sutopo. 2002. Metodologi Penelitian Kualitatif: Dasar Teori dan Terapannya dalam Penelitian. Surakarta: Sebelas Maret University Press.

Suwandi, Sarwiji. 2011. Peran Sastra dalam Pendidikan Karakter bagi Peserta Didik. Makalah Seminar Nasional Sastra dalam Rangka Pekan Sastra Himprobsi, FKIP UNS

Suyanto. 2010. Model Pembinaan Pendidikan Karakter di Lingkungan Sekolah, (akarta: Dirjen Dikdasmen Pendidikan Dasar dan Menengah Kementrian Pendidikan Nasional.

Zuhdi, Darmiyati, (Ed.). 2009. Pendidikan Karakter: Grand Design dan Nilainilai Target. Yogyakarta: UNY Press. 
Agung Prayitno Putro, Herman. J. Waluyo, Nugraheni Eko Wardhani

Zuhdi, Darmiyati. (Ed.). 2011. Pendidikan Karakter dalam Perspektif Teori dan Praktik. Yogyakarta: UNY Press. 